\title{
ENTRE IMPERIAL EYES E "INFORMACIÓN FIDEDIGNA". REFLEXIONES SOBRE LA REPRESENTACIÓN DE AMÉRICA CENTRAL EN TEXTOS DE VIAJEROS ALEMANES
}

Werner Mackenbach*

\begin{abstract}
Resumen: En la construcción de las otredades centroamericanas, los textos de viajes de sujetos europeos y norteamericanos -relatos de viaje, cartas, informes, etc.- han jugado un papel destacado y han tenido sus repercusiones en las literaturas centroamericanas mismas. En la actualidad, se ha desarrollado una polémica sobre el valor y el estatus epistémico de estos textos para la generación de conocimiento histórico sobre las sociedades centroamericanas. El ensayo analiza textos de tres viajeros alemanes en dos momentos históricos claves -a mediados del siglo XIX y en los años ochenta del siglo XX- a la luz de este debate teórico-metodológico y pregunta por la relevancia de los relatos de viaje europeos para las representaciones de las realidades y otredades centroamericanas en las literaturas centroamericanas mismas, desde un enfoque no tanto histórico/historiográfico, sino transhistórico, epistémico y "representacional”.
\end{abstract}

Palabras clave: Relatos de viaje, viajeros alemanes, Centroamérica, representación, otredad, literatura.

Abstract: The texts written by European and North American travelers -travelogues,
letters, reports, etc.- have played a major role in the production of Central American
otherness and have had its repercussions in Central American literatures. Nowadays,
there is an on-going debate about the value and epistemological status of these texts for
the development of historical knowledge about Central American societies. The essay
analyses three texts by German travelers in two historical key moments -mid nineteenth

Fecha de recepción: 03/03/2016 - Fecha de aceptación: 31/03/2016

* Alemán. Doctor en Filosofía y Ciencias Sociales, Universidad Libre de Berlín y Dr. phil. hábil. -título posdoctoral- en literatura hispanoamericana, Universidad de Potsdam. Catedrático Wilhelm y Alexander von Humboldt en Humanidades y Ciencias Sociales y profesor invitado de la Escuela de Historia, Universidad de Costa Rica (UCR). Correo electrónico: werner.mackenbach@ucr.ac.cr 
century and the nineteen-eighties of twentieth century- in the light of this theoretical and methodological debate and asks for the relevance of European travelogues for the representations of Central American realities and otherness in Central American literatures themselves from a transhistorical, epistemic, and "representational" rather than historical/ historiographical approach.

Keywords: travelogues, German travelers, Central America, representation, otherness, literature.

$\mathrm{E}$ xiste una larga tradición de relatos de viaje escritos por viajantes de Europa por Centroamérica que tuvo uno de sus auges en el siglo XIX -tildado como el siglo de los viajes y de los travelogues-, pero que se ha extendido hasta la actualidad. Recientemente, se ha librado una polémica sobre el estatus epistémico de esa literatura de viaje para la generación de conocimiento sobre las sociedades centroamericanas y su historia. ¿Se encuentran en las representaciones de las realidades y otredades centroamericanas de estos textos meras reproducciones de ideologías colonialistas y racistas vistas por imperial eyes que repiten ad infinitum los imagotipos occidentalistas sin posibilidades de romper con los límites de esas formaciones discursivas? ¿O pueden y deben ser entendidos como fuentes imprescindibles, como documentos que brindan "información fidedigna" para la generación de conocimiento histórico?

En su libro publicado durante el emblemático año de 1992, Imperial Eyes. Travel Writing and Transculturation, que entretanto se ha convertido en un trabajo de referencia en los estudios culturales, la canadiense Marie Louise Pratt, profesora de literatura española y portuguesa, resume como propósito principal de su estudio analizar cómo libros de viaje escritos por personales europeos sobre regiones del mundo no europeas contribuyen a crear el "sujeto doméstico" del imperialismo europeo y "de qué manera la literatura de viajes logró que la expansión imperial llegase a ser significativa y deseable para las poblaciones de los países imperiales, aunque sólo unos pocos participaran de los beneficios materiales que el imperio acumulaba". ${ }^{1}$ La estudiosa sostiene:

“¿Con qué códigos la literatura de viajes y exploración produjo -es decir, creó y modeló- 'al resto del mundo' para los públicos lectores europeos en diferentes momentos del proceso expansionista de Europa? ¿Cómo ha producido las concepciones que Europa desarrolló y sigue desarrollando acerca de sí misma en relación con algo que llegó a ser posible llamar 'el resto del mundo'? ¿De qué modo las prácticas significativas de la literatura de viajes codifican y legitiman las

1 Marie Louise Pratt, Imperial Eyes. Travel Writing and Transculturation (London and New York: Routledge, 1992). De aquí en adelante cito de la traducción al español del libro: Marie Louise Pratt, Ojos imperiales. Literatura de viajes y transculturación, trad. Ofelia Castillo (México, D.F.: Fondo de Cultura Económica, 2010), 24. 
aspiraciones de expansión económica y de dominio imperial? ¿En qué puntos socavan esas aspiraciones? [...]". ${ }^{2}$

Uno de los propósitos de su estudio es analizar, partiendo de esas premisas, cómo la literatura hispanoamericana de la primera parte del siglo XIX seleccionó y adaptó los discursos europeos sobre América a su propia tarea de crear culturas autónomas decolonializadas, manteniendo los valores europeos y la supremacía blanca, lo que ella llama "un estudio de la dinámica del proceso de autoinvención criolla". 3

Más recientemente, el historiador costarricense Juan Carlos Solórzano ha cuestionado este posicionamiento e insistido en el valor de fuente de estos textos para la historiografía. "Este tipo de interpretación niega la posibilidad de extraer información fidedigna de los viajeros, o al menos no se plantea esa tarea", critica el enfoque de Marie Louise Pratt y continúa:

"Es decir, no se considera que los viajeros constituyan una fuente de información capaz de darnos imágenes fidedignas del pasado. Al estar encerrados en sus conceptos propios de la cultura de la cual provienen, no pueden hacer otra cosa que mirarnos solo a través de esas imágenes conceptuales. Por eso esta interpretación es incompatible con la disciplina histórica, al adoptar la idea de la supuesta imposibilidad de una comprensión histórica.

Existe una diferencia con los historiadores racionalistas. Para éstos, existe una realidad objetiva, a la cual es posible conocer mediante la aplicación del método histórico. En tal sentido, los viajeros interesan por la información que nos transmiten y para verificar su autenticidad es posible recurrir a la contrastación de testimonios". ${ }^{4}$

El presente ensayo se dedica a analizar textos de viajeros alemanes en dos momentos históricos claves en Centroamérica -a mediados del siglo XIX y en los años ochenta del siglo XX- a la luz de este debate teórico-metodológico en la actualidad, y pregunta por la relevancia de los relatos de viaje europeos para las representaciones de las realidades y otredades centroamericanas en las literaturas centroamericanas mismas. Es decir, su enfoque es no tanto histórico/historiográfico; sino transhistórico, epistémico y "representacional". ${ }^{5}$

2 Ibid, 25.

3 Ibid, 33.

4 Juan Carlos Solórzano F., "Una crítica a los enfoques 'poscolonial' sobre los viajeros europeos y estadounidenses en la Centroamérica del Siglo XIX”, Boletín AFEHC, 56 (marzo 2013), párrafos 74 y 75: http:// afehc-historia-centroamericana.org/index.php?action=fi_aff\&id=3449

5 Utilizo el concepto "transhistórico" en este ensayo en un sentido muy limitado, sin pretender contribuir al debate entre historia, sociología y filosofía sobre historicismo y universalismo; ver por ejemplo, Jürgen Große, Kritik der Geschichte. Probleme und Formen seit 1800 (Tübingen, Alemania: Mohr Siebeck, 2006), 103-146; Frederic Jameson, The Political Unconscious (New York, EE. UU.: Cornell University 
Se trata de los siguientes tres libros: Wanderbilder aus Central-Amerika. Skizzen eines deutschen Malers de Wilhelm Heine publicado en 1853 en Leipzig (Lipsia), Reise nach Central-Amerika de Wilhelm Marr publicado en 1863 en Hamburgo y Nicaragua-Tagebuch de Franz Xaver Kroetz publicado en 1985 en Fráncfort del Meno. ${ }^{6}$

Los tres libros son el resultado de viajes que se emprenden en dos momentos claves de cambio histórico de las condiciones políticas, sociales y económicas en Centroamérica. ${ }^{7}$ Wilhelm Heine y Wilhelm Marr llegan a América Central

Press, 1981); Dean Keith Simonton, "The sociopolitical context of philosophical beliefs: A transhistorical causal analysis", Social Forces (EE. UU.) 54 (1976): 513-523. El concepto usado en el presente ensayo se refiere a formas de percepción y (re)presentación -textual-narrativa- del "Nuevo Mundo" en textos de viaje europeos de diferentes momentos históricos que persisten -y se transforman- a través de diferentes contextos históricos, articulándose en persistentes formas retóricas o "tropos" por un período de varios siglos. Es decir, son formas transhistóricas y al mismo transhistóricas, no ahistóricas. Ver para un debate sobre lo transhistórico en las artes: Paul Crowther, The Transhistoric Image: Philosophizing Art and its History (Cambridge, Inglaterra: Cambridge University Press, 2002); sobre los tropos: Hayden White, $E l$ texto histórico como artefacto literario y otros escritos (Barcelona, España: Ediciones Paidós, 2003); Hayden White, La ficción de la narrativa. Ensayos sobre historia, literatura y teoría (Buenos Aires, Argentina: Eterna Cadencia, 2011).

6 Wilhelm Heine, Wanderbilder aus Central-Amerika. Skizzen eines deutschen Malers (Leipzig, Alemania: Hermann Costenoble, 1853); para este ensayo he utilizado la segunda edición de 1857. Wilhelm Marr, Reise nach Central-Amerika, 2 tomos (Hamburg, Alemania: Otto Meißner, 1863). Franz Xaver Kroetz, Nicaragua-Tagebuch (Frankfurt am Main: Suhrkamp, 1985); en este ensayo hago uso de la edición de 1991. De los libros de Heine y Marr existen traducciones al español: Wilhelm Heine, Impresiones de un pintor alemán en Nicaragua (1851-1852), introd. Juan Carlos Solórzano, trad. Saskia Ostersehlte (Alajuela, Costa Rica: Museo Histórico Cultural Juan Santamaría, 2005); Wilhelm Marr, Viaje a Centroamérica, introd. Juan Carlos Solórzano, trad. Irene Reinhold (San José, Costa Rica: EUCR, Asociación Pro-Historia Centroamericana, 2004). La edición en español del libro de Marr no contiene el prefacio y la introducción -"Vorrede und Einleitung"- del mismo Wilhelm Marr. Por regla general, en este ensayo cito de las ediciones traducidas al español; en el caso del prefacio y la introducción al libro de Marr traduzco del original -y lo indico en una nota al pie-. Del libro de Kroetz no existe una traducción al español, la traducción de las citas es mía.

7 He aquí el resumen de las estaciones de los tres viajes. Wilhelm Heine: mayo de 1851 Nueva York, Islas Turcas, Haití, Jamaica, Islas del Maíz, junio de 1851 San Juan del Norte/Greytown, Río San Juan, El Castillo, San Carlos, Lago de Nicaragua, julio de 1851 Granada, excursiones a León, Masaya, Nindirí, Managua, Rivas, Tipitapa, diciembre de 1851 León, excursión a las Segovias y los distritos mineros de Nicaragua y Honduras, mayo de 1852 visitas a San Rafael del Norte, Totogalpa, Río Coco, Ocotal, Dipilto, Macuelizo, Río Choluteca, Yuscarán, Tegucigalpa, Cerro de Ule, San Martín, Choluteca, Río Negro, julio de 1852 León-Granada-Lago de Nicaragua-Río San Juan-San Juan del Norte/Greytown-Nueva York; en total 13 meses. Wilhelm Marr: 1852 Hamburgo-Escocia-Orkney Islands-Nueva York, Nueva York-Cuba-Jamaica-Santo Domingo-St. Andrews-Costa Mosquita, octubre de 1852 San Juan del Norte/Greytown, Río San Juan, San Carlos, Lago de Nicaragua, San Miguelito, isla San Bernardo, Granada, diciembre de 1852 excursión a Masaya, Nindirí, Nandaime, despues a León vía Managua, Mateare, Nagarote, Pueblo Nuevo, 1853 embarcación en El Realejo a Puntarenas -"Punta Arenas"- en Costa Rica, San José, mayo de 1853 Cartago, colonia alemana "Angostura", junio de 1853 Cartago, julio de 1853 San José, Alajuela-San Miguel-Río Sarapiquí-Río San Juan-San Juan del Norte/Greytown-Cabo San Antonio, Cuba-Golfo de México-desembocadura del Mississippi-Fort Jackson-La Habana-Nueva York -agosto de 1853-, Liverpool-Hull-Cuxhaven-Hamburgo; en total 11 meses. Franz Xaver Kroetz: finales de noviembre de 1984 Munich-Managua, visitas a Masaya, Solentiname, San Carlos-Río San Juan-El Castillo-San Juan del Norte-San Carlos-Solentiname, Corn Island -Navidad 1984-, Managua, visitas a Ocotal, Somoto, Managua 
Entre Imperial Eyes e "Información fidedigna". Reflexiones sobre la representación de América Central en textos de viajeros alemanes

en los primeros años de la década de los cincuenta del siglo XIX, es decir, en un período de suma importancia para la región, que comienza a insertarse en el mercado mundial capitalista y se convierte en uno de los escenarios principales de la confrontación de los intereses geoestratégicos de las potencias mundiales, así como de proyectos de colonización de los países europeos -entre ellos Prusia- ${ }^{8}$ Nicaragua, el país visitado por los dos viajeros, se encuentra en el centro de esta confrontación, por la proyectada construcción de un canal interoceánico que promete el control del comercio internacional -proyecto que exactamente en esa década toma formas concretas-. ${ }^{9}$ Franz Xaver Kroetz visita Nicaragua a fínales de 1984, inicios de 1985 en un período en que el proyecto revolucionario del sandinismo iniciado después del derrocamiento de la dictadura somocista en 1979 vive su primera crisis profunda, con el retiro de las fuerzas burguesas de la Junta de Gobierno de la Reconstrucción Nacional (JGRN) y la creciente presión económica y militar de parte de los Estados Unidos en el marco de la Guerra Fría, que amenaza con transformarse en una guerra declarada con la inminente invasión militar de los Estados Unidos en Nicaragua ${ }^{10}$-una situación que, ante las victorias inminentes de los movimientos guerrilleros, pone a la región centroamericana de nuevo en el centro del interés geoestratégico de las potencias mundiales, especialmente de los Estados Unidos-.

A los tres viajeros-escritores les une - no obstante la considerable distancia temporal, política y cultural-, ${ }^{11}$ por de pronto, el deseo de advertir a sus lectores

-Noche Vieja-, enero de 1985 visitas a Monimbó, León, Poneloya, Ingenio San Antonio, 12 de enero de 1985 Munich; en total menos de 2 meses. Para los viajes de Heine y Marr ver detalladamente: Werner Mackenbach, "De notas que uno ha copiado de otro... Nicaragua a mediados del siglo XIX, vista por dos viajeros alemanes", en: Politica, cultura y sociedad en Centroamérica. Siglos XVIII-XX, (eds.) Margarita Vannini y Francés Kinloch (Managua, Nicaragua: Instituto de Historia de Nicaragua y Centroamérica, 1998), 152-153.

8 Ver Götz von Houwald, Los alemanes en Nicaragua, trad. Rosi de Pereira (Managua, Nicaragua: Fondo de Promoción Cultural-BANIC, 1993), 11-35, 79-90.

9 Ver Miguel Ángel Herrera, Bongos, bogas, vapores y marinos. Historia de los "marineros" del Río San Juan (1849-1855) (Managua, Nicaragua: Centro Nicaragüense de Escritores, 1999), 39-44, 69-70.

10 Ver Wolfgang Dietrich, Nicaragua. Entstehung, Charakter und Hoffnung eines neuen Weges (Heidelberg, Alemania: Heidelberger Verlagsanstalt, 1988), 189-213.

11 He aquí el resumen de los datos biográficos más importantes de los tres viajeros. Wilhelm Marr: *1819 en Magdeburg, †1904 en Hamburgo; trabajaba para el periódico Beobachter an der Elbe -ensayos de orientación liberal-; participante del movimiento democrático de 1848; vivió en Austria y Suiza -de donde fue expulsado por un escrito desaprobado por las autoridades: Das junge Deutschland und die Schweiz-; en 1848 electo diputado por los liberales ante la Asamblea Legislativa de Hamburgo; perseguido por la ley y procesado por la publicación de Mephistofeles -crítica del rey francés-; después de su viaje por Centroamérica -1852-1853- se quedó en Costa Rica hasta 1859 -jefe de una compañía comercial-; regreso a Alemania, publica ensayos y artículos periodísticos -en su mayoría de índole "revolucionaria"-. Peter Bernhardt Wilhelm Heine: *1827 en Dresde, $\uparrow 1885$ cerca de Dresde; estudios en la Academia de Dresde 1848-1849, dibujante en el teatro real; participante del movimiento democrático en la revolución de 1848; a causa de sus actividades tuvo que salir del país; 1849 Norteamérica; a raíz de su viaje a Centroamérica 1851-1852 participó en la expedición de Perry al Japón 1853-1855; conoció a George Ephraim Squier en 1851 -dibujos publicados en Nicaragua, its People, Scenery and Monuments-; 1859 se unió a la expedición prusiana en Asia Oriental; a partir de 1861 participó en la guerra civil norteamericana al lado de las fuerzas 
contra expectativas equivocadas sobre sus textos. Wilhelm Marr sostiene que en sus apuntes tomados en vista a una futura publicación "[n]o me interesaba la forma artística" y tampoco "la vida y mis recursos no me daban la posibilidad de tener el tiempo para estudios e investigaciones, que podrían darle un valor científico al libro"; más bien "[e]ste trabajo efímero tiene un carácter predominante divertido, "to while away the time" ${ }^{12}$ Wilhelm Heine afirma que no tiene la intención de "escribir reportes de viaje que describan a esta o aquella parte de tierra en colores demasiado favorables". ${ }^{13}$ Franz Xaver Kroetz advierte que su diario de Nicaragua -Nicaragua-Tagebuch- "[n]o es un libro sobre Nicaragua", sino "un texto que / martillé durante cuarenta días y noches en / Baviera y Nicaragua / en la máquina"; 14 eso era una diferencia importante: "[...] me doy cuenta que escribo sobre mí y no sobre Nicaragua". ${ }^{15}$

Marr subraya que "me propuse describir -abschreiben = transcribir, copiar- la vida de la manera más fiel y verídica, como se me presentó en sus pormenores, [...] fijé lo que el romanticismo y el optimismo de la mayoría de los turistas dejan desapercibido -la vida real y desnuda". ${ }^{16}$ Heine advierte "anticipadamente que todo lo que pueda llegar a decir aquí, son sólo opiniones e impresiones personales que remito de manera despreocupada y como se me presentan inmediatamente" y señala "[e]n lo que respecta a los eventuales descubrimientos arqueológicos e histórico-naturales que han de realizarse durante la expedición [...] que lo que aquí se dice no debe de ser visto como una doctrina científica"; más bien "[e]se campo le queda reservado a una pluma más diestra que la mía como es la del señor Squier". ${ }^{17}$ En cambio, Kroetz quiere/tiene que "juntar la literatura y la política", es decir -como anota con cierta duda- "escribir sobre una revolución, ¿la forma más antigua de la acción revolucionaria para un poeta -Dichter-?"18 Sostiene: “¿La política y la poesía, son amigos? Sí, se necesitan urgentemente para que ambos no caigan en lo banal o lo inhumano..." ${ }^{19}$ Sin embargo, también él insiste en que quiere describir la realidad como se le presenta, quiere escribir "sincera y claramente sobre las contradicciones": "Relato lo que escuché; como

de la Unión y alcanzó el rango de general; vivió en París y Liverpool -cónsul al servicio del gobierno estadounidense-; 1871 -fundación del Imperio Alemán- regresó a Dresde; publicó varios libros sobre sus viajes. Franz Xaver Kroetz: *1946 en Munich; actor, dramaturgo y escritor; numerosas obras de teatro, poesía y narrativa; 1972-1980 miembro del Deutsche Kommunistische Partei -DKP, Partido Comunista Alemán, República Federal de Alemania-, 1972 y 1976 candidato a diputado en las elecciones generales; varios premios y reconocimientos -literatura, cine, Cruz Federal al Mérito-. Para la biografía de Heine y Marr ver detalladamente: Mackenbach, "De notas...", 153-154.

12 Marr, Reise ..., tomo I, VIII, IX-X. Traducción mía.

13 Heine, Impresiones..., 41.

14 Kroetz, 7.

15 Ibid, 33.

16 Marr, Reise..., tomo I, VIII-IX, X-XI. Traducción mía.

17 Heine, Impresiones..., 41.

18 Kroetz, 15.

19 Ibid, 20. 
soy poeta y no escribano del partido me interesan más los puntos flacos que la propaganda. [...] Escribo sobre lo que veo y no sobre lo que DEBO ver."20

Lo que enuncian los tres autores en diferentes situaciones históricas y desde diversos puntos de vista es la pretensión de llegar, de la percepción individual inmediata a través de su fijación textual, a una forma más auténtica de veracidad que la de aquellas representaciones de realidad basadas en procedimientos "romanticistas", ideológicos y, en general, no perceptivos sino contemplativos/pensativos. De esta manera, los tres autores intentan romper con la larga tradición cultural de percepción del otro, mencionada al inicio de este ensayo, y abrirse paso hacia lo verdaderamente verdadero, "the real thing". Echemos una mirada crítica a algunas de estas percepciones e "impresiones personales", como las reclama Heine. ${ }^{21}$

\section{Semantizaciones del espacio representado 1: De la naturaleza}

Sin lugar a dudas, las descripciones de los tres viajeros transmiten informaciones valiosas sobre varios aspectos de las condiciones de vida en Centroamérica en los respectivos momentos históricos, a partir de su percepción inmediata y su fijación textual. Wilhelm Marr, en su paso por Costa Rica en los primeros meses de 1853, presenta una imagen detallada de la capital:

"San José es una ciudad de cerca de 20.000 habitantes. Tiene una catedral sencilla y sin ningun estilo y dos iglesias más, el Carmen y la Merced; una universidad, un Palacio Nacional, un cuartel, un teatro donde afortunadamente se representa rara vez una comedia, y un cielo que durante cinco meses del año a toda hora y también los otros siete, con excepción de unas pocas horas de lluvia, ostenta una alegre cara soleada. Como en todas las ciudades centroamericanas, la disposición de las calles en ángulos rectos es la predilecta y no hay un solo lugar en la población desde el cual no se divise el campo. De la Plaza Mayor salen ocho calles, dos hacia cada uno de los puntos cardinales, cortadas por otras secundarias en línea recta. Por regla general cuanto más cerca están situadas de la Plaza, tanto mejores son las casas". ${ }^{22}$

Wilhelm Heine anota durante su estadía en Granada, Nicaragua, en julio y agosto de 1851:

20 Ibid, 156, 133, 135.

21 Por cuestiones de espacio y de comparabilidad me concentro en las percepciones de la realidad nicaragüense, que en los libros de Heine y Marr ocupan el mayor espacio y en el libro de Kroetz dominan por completo.

22 Marr, Viaje..., 349. 
"Hace ya tres semanas que regresé a Granada de mi excursión a León $\mathrm{y}$ desde entonces he podido comenzar sin ser molestado mis estudios tanto artísticos como científicos. [...] Las casas cuentan casi siempre de un piso, cuya altura oscila entre los doce y quince pies. Sus puertas miden de seis a ocho pies de ancho y las ventanas con las enrejadas de madera les dan el aspecto de una fortaleza. La descripción de su interior ya antes se las había dado. Las casas están construidas en el estilo de las casas de piedra de Argelia. En el medio se encuentra un gran patio rodeado de corredores de columnas, desde los que se tiene acceso a los diferentes cuartos de la casa. Hacia la calle se encuentra por lo general un vestíbulo [...]". ${ }^{23}$

A su llegada a Nicaragua a finales de noviembre de 1984 Franz Xaver Kroetz anota sus primeras impresiones de Managua:

"Casas de planta baja, rodeadas por jardines, niños de color nogal, hamacas en las casas frente de los televisores, el árbol navideño de plástico en todas partes, y las mujeres con tacones altos. Cuanto más uno se acerque al Lago de Managua tanto más pobre es la gente. [...] La mayoría de la gente se construyó pequeñas casas de planta baja con una habitación - una mezcla de vivienda provisional y bungalow - . De estas hay muchísimas en varios barrios situados a grandes distancias que todos corren hacia el centro: un parque descuidado con mariposas, flores y ruinas". ${ }^{24}$

Cabe destacar que los tres viajeros en sus descripciones aparentemente inmediatas y "secas" recurren a la comparación con lo visto y conocido en Europa y otras partes del mundo, un procedimiento común en la literatura de viaje ya desde los primeros viajeros europeos a América. ${ }^{25}$ Está también presente -hasta en el texto de Kroetz de finales del siglo XX- el estupor que les causaron las (ir) realidades del Nuevo Continente ya a los primeros viajeros, comenzando con Cristóbal Colón. ${ }^{26}$ "Es difícil describir la ciudad, porque NO es", escribe Kroetz a su llegada a la capital nicaragüense: "Por lo menos si uno llega de Europa y tiene en su mente ciudades europeas; en este caso NO es, porque el terremoto literalmente no dejó nada salvo la catedral, el búnker de Somoza, el palacio de gobierno y el Interconti", ${ }^{27}$

23 Heine, Impresiones..., 77, 73.

24 Kroetz, 29, 31.

25 Ver Werner Mackenbach, "El arpa y la sombra, la Conquista y la construcción del espacio americano", Inter Sedes. Revista de las Sedes Regionales de la Universidad de Costa Rica (Costa Rica) 5, n. 9 (2004): 31-32.

26 Ver Ibid, 30.

27 Kroetz, 30-31. 
De manera intertextual -a lo mejor inconsciente- su asombro evoca las primeras impresiones del admiral en su encuentro con las islas caribeñas en su primer viaje en 1492: "Nunca he visto una ciudad como esta", ${ }^{28}$ aunque ahora en clave de espanto.

Esta sensación está también omnipresente en las primeras descripciones de la flora y la fauna de Heine y Marr recién aterrizados en suelo centroamericano, del que pintan imágenes amenazantes y horrorosas. "Neblinas venenosas hacen peligroso el viaje por el río y son la causa de que la desembocadura de los ríos irradie fiebre y muerte", apunta Heine en su viaje por el Río San Juan, en el que avanza -como tantos viajeros europeos antes de él- de la costa caribeña hacia el interior de Nicaragua. Continúa:

\begin{abstract}
"Las riberas están cubiertas por espesos y eternamente húmedos bosques, que están llenos de peligrosos gusanos. Por la noche suena el aullido lastimero del chacal al que con frecuencia se une el rugido del jaguar, un ruido estremecedor. En el río acecha el rabioso caimán a su presa, oculto en el agua o entre el zacate alto y algún animal desprevenido en busca de agua para refrescarse es derribado por una cola escamosa -caimán- mientras que en las copas de los árboles la misma boa constrictor asalta a algunos pobres monos o mata a un pájaro que se empeña en la defensa de su nido. La vegetación es tan extremadamente tupida que solo en pocos puntos de la orilla es posible anclar. [...] A cada paso cierran el camino ramas y lianas $[\ldots]$ ". ${ }^{29}$
\end{abstract}

Marr completa este cuadro, para solamente citar un ejemplo, con la descripción de los daños causados por un huracán y de unos ataques de tiburones durante su viaje a la costa del Caribe nicaragüense. En un pasaje de su texto compara la selva con "un gran muro verde" del que subían "[p]equeñas neblinas [...] al suelo, una malaria maligna"; en vano busca huellas humanas: "Ni el menor rastro de seres humanos o cultura". ${ }^{30}$

En otros momentos la percepción dominada por una sensación de amenaza y espanto es sustituida por descripciones completamente idílicas de la naturaleza tropical y cantos de alabanza de las grandes riquezas naturales y la inconmensurable fertilidad del suelo tropical. La visión del pueblo de San Rafael se le "ofrece a los ojos" de Heine como "un hermoso juego de la naturaleza: hacia el

28 Ibid, 31. Acordémonos de lo que apunta Colón en su Diario de abordo: "Domingo, 28 de Otubre / Fue allí en demanda de la isla de Cuba al Sursudueste a la tierra d'ella más çercana, y entró en un río muy hermoso [...] / Dize el Almirante que nunca tan hermosa cosa vido [...] / Dize que es aquella isla la más hermosa que ojos ayan visto, llena de muy buenos puertos y ríos hondos, y la mar que pareçía que nunca se devía de alçar, porque la yerva de la playa llegava hasta cuasi el agua [...] La isla dize qu'es llena de montañas muy hermosas, aunque no son muy grandes en longura, salvo altas, y toda la otra tierra es alta de la manera de Çeçilia”. Cristóbal Colón, Los cuatro viajes. Testamento (Madrid, España: Alianza Editorial, 1986), 81-82.

29 Heine, Impresiones..., 60.

30 Marr, Viaje..., 115. 
sur se extendía un gran paisaje montañoso cuyos graciosos contornos se asemejan a las montañas de Grecia y el Cercano Oriente." Para Heine, el valle de San Rafael de manera sorprendente "se parecía al valle de Tepliss en Bohemia [...] En una palabra: se veía casi igual a la querida Sajonia". ${ }^{31}$ Marr se entusiasma al llegar a Masaya después de una cabalgada de tres horas por "este paraíso indio":

“donde las frutas lucían en abundancia derrochadora, donde el maíz y la caña de azúcar cubrían el suelo en toda plenitud y sin mucho trabajo, donde los platanares más orgullosos echaban al suelo un claroscuro encantador, mientras que el aire que soplaba sobre sus hojas jugosas temblaba con el ardor del sol. ${ }^{32}$

Más de cien años después, Kroetz describe en palabras casi idénticas "la agresividad del bosque tropical serpenteado por el San Juan"; está "completamente borracho" de su "corporalidad": "Uno tiene la sensación de que el bosque solamente consiste de copas de árboles, por estar tan verde todo. Uno no ve los troncos de los árboles, ni las ramas, solamente se ve un puño verde que se agarra del río". ${ }^{33}$ A esta sensación de abandono se junta la de desamparo que se apodera del autor ante la caótica ciudad de Managua destruida por el terremoto:

"No hay casas que uno podría memorizar. No hay monumentos, ni arterias antiguas, ni pequeñas plazas idílicas. No hay nada para decir: esto, sí, lo memorizo, lo reencuentro. No reencuentras nada. [...] Una mezcla entre campo militar y selva urbana". ${ }^{34}$

A la selva tropical caribeña se junta la jungla urbana. Sin embargo, al igual que en Heine y Marr esta parcepción contrasta con descripciones idílas de las bellezas naturales. En su estadía en la isla Solentiname en el Lago de Nicaragua, Kroetz se entusiasma:

"El verde tropical brilla; veo un avispón negro del tamaño de un huevo caer sobre unas flores gordas; olfateo el aire húmedo, que se calienta en cuestión de minutos. Siento como el sol chupa el rocío; camino unos pasos, acabé de tener frío, y ahora siento como comienzo a sudar". ${ }^{35}$

Esta isla principal del archipiélago del mismo nombre es para él "una de esas 37 islas paradisíacas, donde las aves tienen la palabra todo el día, donde unos caballos piafan orgullosamente por el verde fresco, donde crecen largas salchichas cactáceas en los árboles". ${ }^{36}$

31 Heine, Impresiones..., 133-134.

32 Marr, Viaje..., 195.

33 Kroetz, 76.

34 Ibid, 31.

35 Ibid, 74 .

36 Ibid, 75. 
Entre Imperial Eyes e "Información fidedigna". Reflexiones sobre la representación de América Central en textos de viajeros alemanes

Cabe destacar que esta oscilación entre los imagotipos locus horribilis y locus amoenus, que tiene una larga tradición de varios siglos en la percepción europea del "Nuevo Mundo", ${ }^{37}$ sigue persistiendo en los textos de los viajeros por Centroamérica a mediados del siglo XIX e incluso a finales del XX.

\section{Semantizaciones del espacio representado 2: De la "naturaleza"}

Este movimiento de vaivén está también presente en la percepción de las mujeres tropicales -vistas como parte de la "naturaleza" tropical- que oscila entre asco y deseo. Con eso, los tres viajeros alemanes reproducen uno de los imagotipos con más larga tradición y difusión en la literatura europea sobre América Latina, ya presentes en los informes de los primeros conquistadores que viajan al "Nuevo Mundo" en busca de oro y... mujeres..$^{38}$ En su descripción de Granada en Nicaragua, Heine se fascina del vestuario de las mujeres, especialmente de las capas sociales bajas:

"La vestimenta de las mujeres consiste en un viejo fustán de muselina, amarrado a las caderas desnudas y asegurado en el ruedo inferior. Sobre el pecho llevan las mujeres de las clases más afortunadas un corto chal $[\ldots]$ Las de clase baja lo llevan completamente descubierto". ${ }^{39}$

37 Ver Mackenbach, “De notas...”, 157-158. Sobre el concepto “imagotipo” ver más abajo, nota al pie 53.

38 Estos dos imagotipos se encuentran ya en la obra de Theodor de Bry que a partir de finales del siglo XVI ha jugado un papel importante para la percepción de las Américas en los países de habla alemana. El grabador en cobre de Bry nació en 1528 en Lieja y en 1570 se fue primero a Estrasburgo y después a Fráncfort del Meno perseguido por ser calvinista. En 1618, una de sus hijas se casó con el grabador Mathäus Merian, uno de los "padres" de la cartografía alemana. En Fráncfort, de Bry publicó en 1590 el primer tomo de su obra Reisen in das westliche Indien und das östliche Indien. En los 14 tomos de esta obra en total que se publicaron hasta el año 1634 -después de su muerte en 1598 por su viuda, sus hijos y sus yernos- de Bry ilustró con grabados informes y libros de varios viajeros al "Nuevo Mundo" -entre ellos Hans Staden, Girolami Benzoni, Ulrich Schmidel, José de Acosta, Jean de Léry, Georg Spilberghen y René de Laudonnère- sin jamás pisar tierra en las "indias occidentales" o las "indias orientales". Entre sus grabados se encuentra el famoso de la llegada de Colón a América que ha influenciado de manera decisiva la imagen europea del nuevo continente hasta nuestros días. La primera edición en español de la obra de de Bry, que coetáneamente fue traducida al latín y francés, data del año 1992: Gereon Sievernich, América de Bry (1590-1634) (Madrid, España: Ediciones Siruela, 1992). En su novela sobre Cristóbal Colón, El arpa y la sombra (1979), Alejo Carpentier hace múltiples referencias a estos imagotipos, de manera irónica; ver, por ejemplo, el siguiente pasaje: "Nos hicimos a la mar nuevamente el Domingo, día del Señor, sin apiadarnos de las lágrimas de los cautivos quienes habíamos amarrado en la proa para que guiasen nuestra navegación. Y, a partir de ese día, la palabra ORO será la más repetida, como endemoniada obsesión, en mis Diarios, Relaciones y Cartas. Pero poco oro había en las isletas que ahora descubríamos, siempre poblados de hombres en cueros y mujeres que por todo traje llevaban -como lo escribí a Sus Altezas- 'cosillas de algodón que escasamente les cobijaban su natura' -natura tras de la cual a veces se me iban los ojos a mis españoles- tanto, tanto, que hube de amenazarlos de castigo si, con las braguetas hinchadas como las tenían, se dejaban llevar por algún impulso de lascivia. ¡Si me contenía yo, que también se contuviesen ellos! Aquí no se venía a joder, sino a buscar oro, el oro que ya empezaba a mostrarse, que ya se asomaba en cada isla; el oro que, en lo adelante, sería nuestro guía, la brújula de nuestras andaduras”. Alejo Carpentier, El arpa y la sombra (La Habana, Cuba: Editorial Arte y Literatura, 1985), 116-117.

39 Heine, Impresiones..., 78-79. 
Con entusiasmo describe las "flores de jazmín y flores de vívidos colores" con las que ellas se adornan su "hermoso cabello, en la mayoría de los casos negro como madera de ébano". ${ }^{40}$ Alaba sus "clásicos rostros" y su caminado que tiene "algo en extremo clásico, lo que confiere a todas las figuras un notable encanto". ${ }^{41}$ En particular, Marr repetidas veces expresa su ansia por "las señoritas e indias tiernas" haciendo referencia directa a la descripción de Heine antes citada. ${ }^{42}$ Sin embargo, casi nunca habla abiertamente sobre sus deseos secretos - ¿a lo mejor subconscientes? -, probablemente por respeto a la hipocresía y mojigatería de su público lector alemán de la época. ${ }^{43}$ Un análisis lingüístico y psicoanalítico más preciso, sin lugar a dudas, podría revelarnos más de esos deseos secretos del viajero que habla de "un país tropical, es más, [...] uno que ya está situado dentro de la zona ecuatorial", donde "crecen las piñas y los bananos a flor de labios" -in den Mund wachsen- y donde se asombra mucho sobre "qué clase de frutas podrían ser esas y me informaron: 'All kinds of fruits, pineapples, bananas, platains, mangos, oranges, etc." ${ }^{44}$

Sin embargo, esta mirada concupiscente es contrariada por una sensación de asco y repulsión, que se apodera de los viajeros especialmente en el encuentro con las mujeres indígenas que no pertenecen a la capa social superior descendiente de españoles. En palabras picantes, Marr relata una "aventura" que tuvo en el camino entre Chichigalpa y Chinandega en la región occidental de Nicaragua donde encontró "a una pequeña muchacha india que me pidió, de la manera más inocente, que la llevara adelante -en el caballo- a Chinandega”:
"Se sobreentiende que de inmediato acudí a los ruegos de la piel roja -que se veía encantadora- [...] Nos montamos. El cabello negro, relu- ciente, peinado en largas trenzas, me impresionó fuertemente; al igual que las dos filas de dientes blancos como porcelana y un par de ojos tan ardientes y coquetos como si el dios Amor hubiera caído en un montón de hollín y se asomara por la ventana de los ojos de esta linda niña. [...] Con el brazo derecho tenía que rodear la cintura delgada, suave y elástica de mi acompañante. [...] En ese momento tropezó mi caballo, y tuve que emplear ambos brazos para que mi caballista no besara el

40 Ibid, 79.

41 Ibid.

42 Marr, Viaje..., 108, ver 88-89.

43 Marr presenta sus fantasías de una manera decente y con cierto tono lúdico e irónico: “Ojalá que llegue a tiempo al país donde pueda estudiar de primera mano a las señoritas e indias tiernas. Y les tomaré daguerrotipos y haré un herbario de fotografías; me pasearé con ellas bajo palmeras y plátanos y les contaré historias de ladrones de Hamburgo y sus alrededores. [...] Se enamorará de mí una criolla rica, me regalará su bello corazón y sus plantaciones aún más bellas [...] y ella estará encantada de recibir como tirano de la casa a un 'most distinguished writer and traveller' [...]". Ibid, 108.

$44 \mathrm{Ibid}, 102$. La traducción al español de este pasaje es muy poco precisa y no deja entender su sentido sexual subyacente. El original en alemán habla de las piñas y los bananos que a uno le crecen directamente en la boca/hacia adentro de la boca -"wachsen einem die Ananas und Bananen nur so in den Mund hinein"-. Ver Marr, Reise..., 138. 
polvo. Y para estar más seguro de que no besara el polvo, la coloqué en una posición más cómoda y ya le quería dar un b...". 45

Pero ya el siguiente párrafo continúa de manera brusca y tajante:

“¡Ay de mí! El ángel guardián de la virtud se envolvió en un olor que no lo puede exhalar ni el mejor croata u otro devorador de cebollas. Todas mis ilusiones, todo mi olvido de mi mismo se había ido al diablo. Habría preferido unas cuantas bofetadas. Está escrito que el carcaj de Amor, en este país solo tiene látigos para mí. Desde ese momento se esfumó el deleite romántico. Estaba satisfecho antes de cenar". ${ }^{46}$

Sobre una noche en la casa de Niña Chepita y su hija "famosa tanto por su belleza como por su accesibilidad" 47 en Nagarote en el camino a León, Marr anota:

"Con miradas avaras que curiosas observaron nuestro equipaje, en especial nuestras armas. Chepita nos insinuó guardar ambos en su pequeña alcoba, por más seguridad y también me ofreció a mí un espacio allí, lo que, sin embargo, rechacé decididamente, porque no quería disfrutar donde otro quizá se habría sentido como un dios". ${ }^{48}$

No es muy diferente el comportamiento de nuestro hombre viajero a finales del siglo XX. Kroetz no solamente muestra un vivo interés por "los abundantes senos"49 y el trasero de su patrona en Managua "el que tira como una pieza de artillería de un lado al otro". ${ }^{50}$ En la Navidad que pasa en el Caribe nicaragüense se apoderan de él unas sensaciones muy parecidas a las del caballero del siglo XIX en el oeste nicaragüense, con una diferencia marcada el lenguaje mucho más directo, vulgar y brutal de Kroetz:

"Más tarde vamos a otro bar; ¡reggae oscuro con los bajos retumbantes y los enormes cuerpos negros de los negros que se mueven en el mismo lugar agitando sus culos imponentes! Estoy sentado entre ellos, apretado, sudando, sin poder respirar y pienso: follar una vez así, solamente una vez con esta firme vitalidad sin pensar, y estaría curado. Me imagino a las mamitas gordas y rítmicas y los imponentes muchachos

45 Marr, Viaje..., 287.

46 Ibid, 287-288. En el original la segunda parte de la última frase está escrita en francés: "Ich war satt avant le diner". -Ver Marr, Reise, tomo I, 53-. La traducción al español ignora este detalle, mientras en otros pasajes mantiene las oraciones o palabras en otros idiomas -inglés y francés- y explica su sentido en notas al pie.

47 Marr, Viaje..., 228.

48 Ibid, 229.

49 Kroetz, 34.

50 Ibid, 37. 
y me imagino esa follada tan difícil como algo completamente FÁCIL $[\ldots] "{ }^{51}$

El cuerpo femenino no es solamente un objeto de la fantasía masculina, también está disponible todo el tiempo, listo para la entrega, la prostitución -al igual que en las fantasías del viajero a mediados del siglo XIX-, como Kroetz relata de sus experiencias en la playa caribeña en una mezcla de atracción y repulsión muy similar a la de Marr:

"Contiguo a mi cabaña se encuentra el comercio más antiguo del mundo, me atraen a la choza y allá yacen tres hembras negras y me estiran todo que sería bueno para follar. -Lo haría pero tengo un miedo tremendo de lo que tienen entre las piernas - ise dice que es un montón!-". 52

\section{Semantizaciones del espacio representado 3: De la cultura}

Con estas descripciones, los tres viajeros se colocan en una larga tradición de la percepción europea/alemana del "Nuevo Mundo", que ha sido determinada por una serie de "imagotipos", presentes durante varios siglos en diferentes contextos históricos y en diversos autores. Las anotaciones de Heine y Marr al igual que el diario de Kroetz se caracterizan por varios de esos imagotipos -muchas veces entremezclados- que han sido analizados por la imagología. ${ }^{53}$

En particular, las representaciones que Marr da del "otro (centro)americano" se caracterizan por una serie de prejuicios racistas. Para él, los habitantes de Nicaragua son "indígenas desnudos", "salvajes auténticos", ${ }^{54}$ caracterizados por "la pereza de la raza sucia". ${ }^{55}$ Los indígenas son una raza inferior y "un negro nunca llegará al nivel cultural de un blanco". ${ }^{56}$ En un pasaje, Marr habla de las tripulaciones de unas goletas en el puerto de Greytown en el Caribe nicaragüense

\section{Ibid, 91 .}

52 Ibid, 83.

53 Ver Marlene Rall, "La otra lectura. Relaciones de viajes y los descritos como lectores", en: Letras comunicantes. Estudios de literatura comparada, (eds.) Marlene Rall y Dietrich Rall (México, D.F.: Coordinación de Difusión Cultural, Universidad Nacional Autónoma de México, 1996), 418. Marlene Rall habla de diez imagotipos, en referencia a los estudios de Siebenmann y König; ver: Gustav Siebenmann y Hans-Joachim König (eds.), Das Bild Lateinamerikas im deutschen Sprachraum. Ein Arbeitsgespräch an der Herzog August Bibliothek Wolfenbüttel, 15.-17. März 1989 (Tübingen, Alemania: Max Niemeyer, 1992). En mi ensayo publicado en 1998 propuse completar estos diez imagotipos por un undécimo: "Los americanos como seres humanos inferiores a los europeos civilizados, expresión de un abierto racismo contra los indígenas". Mackenbach, "De notas...", 159.

54 Marr, Viaje..., 118. El original en alemán habla aún más claramente de "Wilde in optima forma". Marr, Reise..., tomo I, 160. Traducción mía.

55 Marr, Viaje..., 146.

56 Ibid, 457, ver también 156-159, 207. En el libro de Heine solamente encontré un pasaje abiertamente racista en el que hace referencia a los indígenas de Honduras; ver Heine, Impresiones..., 159. 
"cuyas tripulaciones constaban de negros, hombres, mujeres y niños". ${ }^{57}$ Desarrollo toda una clasificación de las diversas "razas" en Nicaragua: negros, blancos, criollos, mestizos, mulatos, zambos, indios ${ }^{58}$ Con base en esta categorización, compara las "fisonomías nicaragüenses" con diferentes animales: "Un tercio tigre, un tercio mono y un último tercio cerdo formaban, en figura humana, al zambo de Nicaragua." 59 Para él, los nicaragüenses son "medio salvajes parecidos a monos", "caricaturas porcinas de la deidad", cuyos aspectos "me hizo sonreír sobre la afinidad electiva planteada por nuestros ideólogos europeos". ${ }^{60}$ Tajantemente, resume sus observaciones sobre las poblaciones negras o de color -" $[\mathrm{e}]$ 1 negro de Jamaica", "los negros de Haití", "el negro español"-:.61 "Realmente sería una lástima, pensaba yo muchas veces, si fuera verdad que todos los seres humanos son hermanos". ${ }^{62}$ Después de un encuentro con un hombre "joven, bastante blanco" que "hablaba un francés bastante fluido y era un hombre tan instruido como ya no esperaba encontrar en ese país" en su viaje por el Río San Juan apunta en su diario: "13 de noviembre de 1852, Fuerte de San Carlos: $\mathrm{He}$ descubierto a un ser humano". ${ }^{63} \mathrm{Y}$ como si no quisiera dejar ninguna duda sobre su racismo, agrega en otra parte del libro: "Los seres humanos son la disonancia

57 Marr, Viaje..., 118

58 Veamos su interpretación del desarrollo humano y social en Centroamérica después de la independencia de España: "La constitución y las leyes son excelentes en este país", escribe sobre Nicaragua, y continúa: "Es la quintaesencia de las Ordenances de Bilbao y el Code de Napoléon, la mejor selección de todos los derechos humanos y constitucionales, pero 'les singes sont faits pour grimper sur les arbres et non pour danser' -los monos son para escalar árboles y no para bailar-. Cuando estas repúblicas se quitaron de encima el yugo español, los criollos afeminados ya habían dicho demasiado como para proveerse a sí mismos y a los demás, de la bendición de una organización humana. Las guerras civiles que surgían y se hicieron permanentes, habían convertido a los esclavos negros en soldados de los partidos políticos en vez de campesinos. Los negros se mezclaron con los indios nativos y así se formó esta raza mestiza predominante de los zambos, la cual en ninguna parte de la tierra se ha formado tan definitivamente. Entre los descendientes de esa mezcla sobresalen todas las malas características del negro y del indio, pero las buenas se perdieron. El mulato que surgió del negro y el blanco, también hereda las malas características de los blancos y conserva las malas del negro, pero física y espiritualmente está a un nivel mucho más elevado que el zambo o negro-indio. [...] El zambo sucumbe ante el clima y las enfermedades endémicas casi en igual medida que el indio puro; hay en él una esencia insalubre. También es, en más de un aspecto, menos hábil que el mulato". Ibid, 249.

59 Ibid, 124.

60 Ibid. Cabe destacar que su criterio en relación con la población costarricense es diferente: "Cierto es que entre todos los novohispanos, los costarricenses son los que tienen menos mezcla de sangre indígena y los más puros, así como los menos infectados, por este motivo, de vicios físicos. En Costa Rica el cáncer social consiste en la mezquina codicia y la falta de un alto espiritú de especulación. [...] Para el filántropo resulta duro, pero el hombre atezado es así, y está muy bien que podamos tomar en Europa el buen café de Costa Rica, después de haber impedido al indio degradado y sumido en la pereza que nos dificulte por más tiempo la cultura. Don Braulio fue un despota inteligente, tal como lo necesitaba un país primitivo, y quizás el gobernante más puro y desinteresado que ha tenido Costa Rica”. Ibid, 366, 380. Parece que ya a mediados del siglo XIX el mito de la Costa Rica "blanca" circulaba incluso entre los viajeros extranjeros.

61 Ibid, 124.

62 Ibid, 125.

63 Ibid, 155. 

$[\ldots]^{\prime \prime} \cdot{ }^{64}$

Este racismo marcado de Wilhelm Marr podría sorprender si uno toma en cuenta que antes de hacer su viaje a Centroamérica militó en el movimiento democrático "Das Junge Deutschland" -La Alemania Joven-, sin lugar a dudas el movimiento político más progresista en los estados alemanes de su época que luchó contra el ancien régime y por ideas liberales y los derechos humanos. ${ }^{65}$ Sin embargo, su posición muestra que los antiguos prejuicios y clichés -los imagotipos mencionados- se resistían a las ideas modernas de la fraternidad universal y de la igualdad de derechos para todos los seres humanos independientemente de su "raza", su género o su confesión. ${ }^{66}$

La aparente fuerza de resistencia de los viejos prejuicios también se muestra en el libro de Kroetz. Eso también podría sorprender porque Kroetz militó en la izquierda alemana de los años sesenta y setenta del siglo XX, que estuvo orgullosa de su compromiso aparentemente incorruptible con los derechos humanos y el internacionalismo. ${ }^{67}$ Con muy pocas variaciones, se encuentran también en el libro de Kroetz prejuicios similares a los de Marr, aunque no se vale de las

64 Ibid, 215.

65 También Heine fue activista de ese movimiento. Ver nota al pie 11 y más detalladamente: Mackenbach, "De notas...", 162.

66 Von Houwald señala que Marr combinó sus ideas liberales con un ardiente antisemitismo y comenta: "Los lemas de libertad, democracia y derechos humanos de los cuales hicieron alarde tanto los militantes de la llamada generación del ' 48 fueron, en la práctica, una palabrería hueca. Nadie respetaba los derechos de los indios; un demócrata entusiasta como Wilhelm Marr no encontraba objetable exportar trabajadores alemanes a los territorios tropicales de América, bajo condiciones que seguramente habrían provocado la muerte de aquellos infelices antes de finalizar su contrato". Von Houwald, 15. El caso de Wilhelm Marr es especialmente interesante porque muestra que las viejas ideas antisemitas se entremezclaban con las de los movimientos político-sociales progresistas influenciados por la revolución francesa. Marr fue uno de los primeros que en los países de habla alemana propagó el anarquismo. En 1879 comenzó a utilizar el concepto antisemitismo. En febrero de 1879 se publicó en Berlín su folleto de propaganda Der Weg zum Sieg des Germanenthums über das Judenthum - vom nichtconfessionellen Standpunkt aus betrachtet -El camino hacia la victoria de la germanidad sobre el judaísmo - vista desde una perspectiva no confesional- que en el mismo año tuvo doce ediciones. En ese año también fundó la efímera liga antisemita y fue editor de su órgano oficial Die neue deutsche Wacht-La nueva guardia alemana- hasta 1880. En su estudio sobre Marr, Moshe Zimmermann señala que Marr se distanció en sus escritos del tradicional antisemitismo religioso y sostuvo que los judíos eran una raza ajena de "parásitos" que con éxito ejercía la explotación de Alemania. Elucidó ese cambio de paradigma de religión a raza con la inserción del concepto "antisemitismo" en el discurso político-social de la época. Sin embargo, no está claro si fue el primero en crear el concepto, porque el adjetivo antisemita ya está documentado a partir del año 1873. Ver: Moshe Zimmermann, Wilhelm Marr - The Patriarch of Antisemitism (New York y Oxford: Oxford University Press, 1986), especialmente 45.

67 Como ya fue señalado en la nota al pie 11, Franz Xaver Kroetz fue uno de los fellow travellers más prominentes del partido comunista (DKP) en la República Federal de Alemania (BRD), fiel seguidor de las políticas de la República Democrática Alemana (DDR) y la Unión Soviética. Sin embargo, en el momento de su viaje a Nicaragua ya había abandonado el partido, como escribe en su libro: “[...] desde que me retiré del DKP tengo muy pocas ganas y muy pocos argumentos para mi comunismo restante. No quiero seguir este camino. Lo siento así incluso en Managua”. Kroetz, 50. Parece que, al igual que en el caso de Marr y Heine, que dejan Alemania desilusionados por la derrota del movimiento progresista, también un motivo del viaje de Kroetz es su sensación de frustración política. 
clasificaciones raciales/racistas de Marr -en la Alemania de finales del siglo XX, momento en el que escribe Kroetz, no aceptadas en el discurso público-. Para él, Nicaragua es un país "sin industria e historia propia" ${ }^{68}$, poblado por "pueblos primitivos" ${ }^{69}$ Sobre Corn Island en el Caribe nicaragüense anota: "Viven entre el paraíso y la mierda, no hay posibilidades de empleo, nada salvo palmeras, mar y selva -es muy lindo si uno no TIENE que vivir aquí-, no hay la posibilidad de irse, y la isla deja un aspecto moribundo". ${ }^{70}$

Después de una "visita a 'mi' gente" en los barrios más pobres de Managua, comenta: "La mayoría de la gente en los países en vías de desarrollo no piensan políticamente [...] una buena política es tener mucho en la olla -me dice uno de los habitantes". ${ }^{71}$ Aquí también se asoma un racismo -y eso a finales del siglo XX- que les atribuye a los así llamados "pueblos primitivos" rasgos comunes de inferioridad, que ahora no necesariamente se relacionan con características biológicas o fisionómicas -aunque no está completamente libre de esas, como se ha visto-, sino se basan en la supuesta falta de cultura e historia, así como de un deficiente desarrollo económico.

\section{Semantizaciones del espacio representado 4: De la política}

Los tres viajeros-autores dan detalladas descripciones de la situación político-institucional, particularmente de los órganos de Estado en Nicaragua. Wilhelm Heine escribe el primer capítulo de su libro ya antes de pisar tierra nicaragüense. Resumiendo las informaciones sobre el país recopiladas de otros libros e informes, describe su posición geográfica, sus fronteras, su topografía, su población, sus grupos étnicos, el clima, la organización administrativa regional, la constitución política y su forma de gobierno. Entre sus observaciones destacan las que escribe sobre la "fertilidad ilimitada" " del suelo nicaragüense, los grupos étnicos en la región caribeña, la "costa atlántica, o como es llamada generalmente, la costa mosquitia" -"La población es escasa y está compuesta por indios de la tribu de los Caribes, negros que huyeron de las islas de las indias orientales y de una raza mestiza surgida entre ambos" ${ }^{73}$, y el sistema político del país del que hace grandes elogios:

"La constitución de Nicaragua es de corte liberal y dominan por todas partes y entre todas las clases sociales los sentimientos de simpatía por los Estados Unidos; por todos lados irradian la bondad y la hospitalidad. El gobierno está compuesto por un primer ministro que es elegido

68 Kroetz, 57.

69 Ibid, 79.

70 Ibid, 90 .

71 Ibid, 101.

72 Heine, Impresiones..., 43.

73 Ibid, 44. 
cada año, una casa de representantes y un senado, éste último elegido por dos años y el primero sólo por uno". ${ }^{74}$

Esta descripción imparcial e incluso benévola cambia radicalmente apenas Heine aterriza sobre San Juan del Norte o Greytown en la Costa del Caribe. Parece que ese primer contacto con la realidad nicaragüense fue un gran choque que determina de manera irreversible la visión con que Heine, a partir de ese momento, percibiría la situación del país a lo largo de todo su viaje recién comenzado. En junio de 1851 anota sus primeras impresiones de Greytown, que culminan en la observación: "San Juan de Nicaragua: Greytown [...] / En cuanto a cultivos cabe decir que no los hay [...]". ${ }^{75}$ A partir de ese momento, sus observaciones sobre los órganos de Estado en Nicaragua están llenas de menosprecio e ironía.

En su relato escrito quince meses después, Wilhelm Marr hace suyo este tono y se burla del "fabuloso rey de Mosquitia" o "Mister King". ${ }^{76}$ Estos juicios llenos de menosprecio de los dos viajeros se repiten en sus observaciones de las instituciones y funcionarios estatales nicaragüenses, en general, conforme se avanza hacia el interior del país y la región del Pacífico. En San Carlos -en el camino entre el Caribe y la región del Pacífico-, Heine se burla de las condiciones en las que viven una o dos docenas de soldados que forman la guarnición del antaño fuerte colonial. Un cañón viejo y completamente oxidado y la bandera nicaragüense parecen ser los únicos símbolos de Estado. ${ }^{77}$ Quince meses después, Marr repite en casi las mismas palabras las observaciones de Heine, ahora en El Castillo sobre el Río San Juan. Marr describe la comandancia como "la última y más miserable choza de caña":

"Ahí, en una hamaca, debajo de la cual jugaban unos cerditos alegres, encontré a un viejo cano, lanudo, medio desnudo y roncando, a quien consideré que era algún sirviente y lo sacudí con rudeza para que se despertara. Cuando pregunté por el señor comandante, el individuo que parecía el hermano gemelo de un orangután, saltó en sus pies y habló: -Soy yo, a la disposición de Vd." ${ }^{78}$

Estas observaciones continúan de la misma manera en las siguientes estaciones de viaje: Granada, Managua, León, etc. Por ejemplo, Marr relata de su visita en el "apartamento del presidente", que "no difiere de las casas de las demás familias de clase alta en el país"; sin embargo, apunta, "nos llevamos un número

74 Ibid, 45.

75 Ibid, 54. Desafortunadamente, esta traducción es muy deficiente. En el original dice: "San Juan de Nicaragua oder Greytown [...] / Cultur ist gar keine da [...]" Heine, Wanderbilder ..., 63. "Cultur" en alemán tiene dos connotaciones: cultura y cultivo. En la traducción al español se pierde la noción de cultura.

76 Marr, Viaje..., 121.

77 Ver Heine, Impresiones..., 68.

78 Marr, Viaje..., 145. 
Entre Imperial Eyes e "Información fidedigna". Reflexiones sobre la representación de América Central en textos de viajeros alemanes

considerable de pulgas de la habitación del hombre al cual le estaba confiado el destino de la Republica". ${ }^{79}$

En general, los dos viajeros pintan Nicaragua como un país sumergido en el caos, especialmente con respecto a la seguridad pública, la violencia y los conflictos armados. También la sitiación política les preocupa. Heine, por ejemplo, ve el mayor obstáculo para el desarrollo económico en el estado miserable de las comunicaciones viales. ${ }^{80} \mathrm{El}$ trasfondo de esta preocupación sobre la situación del transporte es el interés de los dos por el proyecto de construcción de un canal interoceánico, que iba tomando una intensidad siempre más grande a partir del descubrimiento de yacimientos de oro en California. ${ }^{81}$ Heine y Marr dedican numerosas páginas de sus libros a este tema; informan sobre conversaciones con ingenieros, se refieren a estudios topográficos y presentan mediciones y evaluaciones de la factibilidad de la construcción del canal..$^{82}$

Ambos coinciden en que el proyecto del canal y la actividad de la Compañía Accesoria del Tránsito eran parte de una misión civilizatoria llevada a cabo por los Estados Unidos en Nicaragua. Heine pregunta: “¿Cuándo este país tan privilegiado en todos los respectos por la naturaleza ya no va a caer en la

79 Ibid, 223. Es notable que los juicios de Marr sobre los personajes políticos de Costa Rica no difieren mucho de esas caracterizaciones. Sobre una compra en una tienda de San José apunta: "Con el objeto de comprar fósforos entré en una tiendecilla mezquina situada en la calle del Carmen. Detrás del mostrador y rodeado de un verdadero caos de todos los objetos posibles e imposibles estaba un hombre pequeño y algo enjuto, cuya fisonomía era, a primera vista, la más vulgar del mundo, al lado de una señora vestida con sencillez. [...] Puse mi real en el mostrador y recibí mis fósforos. El me miró como admirado de que yo no regatease. Aquel señor era nada menos que don Manuel José Carazo, ministro de Hacienda y de Guerra de la República de Costa Rica, el hombre más sesudo, hábil, talentoso y, desde el punto de vista centroamericano, el más cortés de todo el país. La señora era su esposa doña Mariquita. Es una lástima que el gran talento de don Manuel se malgaste en cosas de poca monta". Marr, Viaje..., 365. Sobre su encuentro con el presidente de la república anota: "Manifesté un día el deseo de conocer a los notables de la ciudad.

-Para esto venga usted conmigo el próximo domingo a las peleas de gallos -me contestó el instructor de la milicia costarricense, un señor von Salisch de Polonia-. [...] Ahí se encontraba un señor de pequeña estatura y cara llena y astuta, vestido de frac negro y pantalones amarillos de casimir. Era el jefe de Estado, don Juan Rafael Mora. El hombre no es un genio, pero cuentan que es un gran socarrón. Según dicen, tan solo se ocupa en los asuntos del Gobierno cuando está en juego su interés personal, y deja la política menuda en manos de su ministro Carazo, en tanto que un francés, monsieur Adolphe Marie, atiende la alta política, es decir, la correspondencia con las naciones extranjeras, la cual nunca se contesta. [...] El general Mora, que parece un cacique indio anémico vestido de frac, le disputará la palma de primer jugador de gallos a don Juan Bautista Bonilla en los anales de la República”. Marr, Viaje..., 370.

80 Ver Heine, Impresiones..., 146-147.

81 Ver von Houwald, 13; Herrera, 13, 16-17, 39, 41-42. Cabe señalar la estrecha relación que tenía Heine con el diplomático, agente, viajero y arqueólogo amateur estadounidense George F. Squier, un ardiente defensor del proyecto canalero. Squier viajó por Nicaragua en 1849 y en 1852 publicó su libro sobre ese viaje en Nueva York: Nicaragua: its people, scenery, monuments, and the proposed interoceanic canal (New York, EE. UU.: D. Appleton \& Co.). Heine emprendió su viaje a Centroamérica por invitación de Squier, quien planeaba publicar un segundo libro sobre Nicaragua. Por razones desconocidas, Squier no pudo acompañarlo en ese viaje. La -tercera- edición del libro de Squier en español publicada en 1989 por la Editorial Nueva Nicaragua en Managua, Nicaragua, sus gentes y paisajes, contiene varias ilustraciones de Heine hechas durante su viaje. En su libro, Heine hace referencia explícita a las anotaciones y cálculos de Squiers sobre el futuro canal; ver Heine, Impresiones..., 45-48; Herrera, 40-41.

82 Ver, por ejemplo, Heine, Impresiones..., 64-65; Marr, Viaje..., 125-126, 156-159. 
depresión siempre más profunda a causa de la debilidad e insidia de sus dirigentes?". E inmediatamente presenta su respuesta: "Muy probablemente no antes que ondeen las estrellas y franjas sobre todo el istmo, y para la salvación de la civilización hay que desear que eso suceda muy pronto". ${ }^{83}$ Para Heine, el pueblo nicaragüense es un ejemplo histórico de una sociedad degradada a causa de una persistente tiranía. Según su criterio, la independencia solamente le traía la demoralización para los nicaragüenses: "Hasta ahora no he conocido ningún pueblo que es menos capaz de autogobernarse y una especie de gobierno ruso le sería un verdadero beneficio". ${ }^{84}$

Más de cien años después, Franz Xaver Kroetz parece argumentar desde la posición exactamente opuesta con respecto a las causas de la inestabilidad política y los problemas económicos del país. De todas maneras, en los pasajes que dedica al tema, domina la denuncia de la intromisión de los Estados Unidos como causa principal de la crisis nicaragüense; no obstante, también tiene sus dudas en cuanto a un posible "gobierno ruso" -en este caso soviético-: "La burguesía local y sus expertos se rindieron y vinieron los consultores del socialismo real. Con estos consultores se importan todos los errores del socialismo real $[\ldots] "{ }^{85}$ Sin embargo, más allá de este posicionamiento ideológico se puede divisar semejanzas sorprendentes con sus antecesores. Al igual que Heine y Marr, Kroetz comienza a escribir su libro antes de llegar a Nicaragua. En estos primeros pasajes se encuentran apuntes en los que resume la situación del país desde su perspectiva: "La situación de Nicaragua está siempre peor [...] 'a cada hora' esperan una invasión de los yanquis", de ahí el motivo de su viaje:

"iQuiero ir para allá, quiero ser parte, quiero verlo! Para que quede claro: viajo a Nicaragua porque creo en una invasión de los yanquis, porque esta agresión y primitivismo que se han convertido en ese bulto de carne que es la mayoría de los yanquis, sea GI o turista, provoca mi odio, desde que he comenzado a pensar". ${ }^{86}$

Quiere defender la ilusión revolucionaria del proyecto sandinista contra esta agresión -como se ha visto al inicio de este ensayo, con las armas de un escritor (Dichter) y con la pretensión de unir la poesía y la política-.

Pero ya el primer encuentro con el país le lleva -muy similar a lo que le pasa a Heine- a un cambio de su percepción. "La situación está tranquila", comienza la primera anotación y Kroetz continúa con cierto tono de desilusión: "No hay tanques, no hay trincheras; solamente unos pocos soldados parados en

83 Heine, Wanderbilder ..., 163. -Traducción mía-. En la traducción al español del libro de Heine faltan nueve páginas -157-165-.

84 Ibid, 164. Traducción mía.

85 Kroetz, 108.

86 Ibid, 13-14, ver 15-23. 
el calor. En el aeropuerto, entrando al país. [...] Ahora estoy aquí. Después de llegada una primera corta, profunda depresión". ${ }^{87}$

No solamente la no existente invasión de los Estados Unidos le desilusiona al poeta, más bien, inmediatamente después de sus primeras impresiones de Managua comienza a dudar del proyecto revolucionario y del suyo personal: "¿Estoy recorriendo esta Managua malditamente vasta para encontrar las huellas de lo que en mi mente es una 'revolución', solamente en mi mente?" ${ }^{88}$ Este proceso de desilusión creciente por la situación política, social y económica de Nicaragua se prolonga a lo largo de todo el libro. De hecho, Kroetz presenta -en contraposición a su afirmación de no escribir un libro sobre Nicaragua- largos pasajes acerca de la situación política y social en los que no vacila en expresar juicios llenos de generalizaciones, ${ }^{89}$ sin tener ni siquiera conocimientos rudimentarios del español y con muy pocas posibilidades de comunicarse en inglés -como él mismo admite- .90

Ciertamente, sigue dominando su visión ideologizada de los Estados Unidos como culpables principales de la situación en Nicaragua: "Se destruye el país joven con todos los medios de los que dispone el capitalismo". ${ }^{91}$ Sin embargo, también crece su desilusión por las actitudes y opiniones políticas de la población nicaragüense, así como por las instituciones políticas del país. Así se burla de la actitud antisandinista y pro-estadounidense de la gente en la isla caribeña Corn Island:

"Aquí todos solamente piensan en Donald Duck. Para ellos América [sic, es decir, los Estados Unidos] es fuerte, joven, súper - prefieren ser gobernados por los yanquis que por los de la costa del Pacífico. [...] La gente no tiene otras raíces más profundas que las que van al supermercado en Miami, anhelan el dinero americano [sic, es decir, estadounidense] y este ya no llega hace cinco años. No piensan políticamente, piensan en lo privado. Ajustan sus cuentas con la revolución así: ¿qué me pone en la olla?’.92

También se burla de los revolucionarios:

"Los sandinistas pensaron de una manera simple: Expropiamos a Somoza y ya tendremos el socialismo. Entretanto se sabe que no es así. No se sabe qué y cómo será un socialismo centroamericano.

87 Ibid, 29.

88 Ibid, 33 .

89 Ver Ibid, 40-43, 46-49, 53-53, 56-58, 86-90, 106-110, 126-133, 155-158.

90 Ver Ibid, 68.

91 Ibid, 57.

92 Ibid, 86-87. 
Deshacerse de un explotador no significa todavía el progreso. Incluso puede ser un retroceso". ${ }^{93}$

Toda la población, en general, le desilusiona porque muestra muy poca conciencia revolucionaria:

\begin{abstract}
"Una mala y desilusionada experiencia de viaje: la gente no anhela la justicia, la libertad, la dignidad. Solamente preguntan por lo que se sirve en el plato, y les vale verga quién lo sirve [...] Cuanto más bajas son las capas sociales tanto más pesa la Santísima Trinidad de una tradición secular: religión, represión y miseria. Si la miseria se agudiza, esta mezcla se vuelve explosiva -no en dirección de más justicia y libertad, sino buscando al "hombre fuerte" y: mejor recibir golpes y pan que no tener golpes ni pan". ${ }^{94}$
\end{abstract}

La conclusión de esta percepción de las circunstancias políticas en Nicaragua que se lee entre líneas puede formularse así -en alusión al juicio de Heine: "Cultur ist gar keine da" -No hay cultura, de todo-: No hay revolución -invasión-, para nada. "Ella dice", escribe Kroetz sobre su patrona en Managua, "que de vez en cuando no hay papel higiénico; y si lo hay es más caro que todos esos libros y la calidad del papel es la misma". Le enseña una edición de las Obras de Carlos Fonseca, "el gran pensador revolucionario de la revolución nicaragüense que no vivió el triunfo sino fue asesinado"; sin embargo, sospecha que algunos de los que compraron esos libros "no los usan para leer sino para cagar". ${ }^{95}$

\title{
¿Información fidedigna o mirada imperial?
}

La lectura crítica de los textos de los tres viajeros alemanes del siglo XIX y XX ha mostrado que distan mucho de "describir -abschreiben = transcribir, copiar- la vida de la manera más fiel y verídica"96 como lo reclama Wilhelm Marr en la introducción a su libro. Su percepción de América Latina y su representación textual/literaria se colocan en una larga tradición de modelos de pensamiento y comprensión que han dominado la visión europea del otro, nuevo mundo -por lo menos en su mainstream $-{ }^{97}$ Pero, ¿quiere decir eso que rige un

93 Ibid, 127-128.

94 Ibid, 130.

95 Ibid, 38.

96 Marr, Reise..., tomo I, VIII-XIX. Traducción mía.

97 De manera presuntuosa, Marr habla de toda una tradición intertextual: "Muy pocos turistas realmente han vivido entre los indígenas y echado un vistazo más que superficial a la vida casera y familiar y, de esta manera, a su carácter; pero con afán han coleccionado apuntes, de los cuales, después uno ha copiado de otro." Marr, Viaje ..., 210. Marr se refiere a unos "notables alemanes" -Ibid, 185- que visitaron Nicaragua e incluso publicaron libros enteros sobre el país para promover la inmigración de colonos alemanes, sin jamás salir de Managua y hacerse un criterio personal por su propia observación de las regiones del país 
Entre Imperial Eyes e "Información fidedigna". Reflexiones sobre la representación de América Central en textos de viajeros alemanes

determinismo sobre estos viajeros y sus textos que no les permite a ellos romper con esos patrones y deshacerse de ese bagaje semántico/ideológico -por lo menos parcialmente-? Como critica Juan Carlos Solórzano la posición de Marie Louise Pratt:

"Cuando se hace énfasis en la búsqueda de imagotipos comunes en los viajeros, pareciera considerarse que todos los viajeros compartían un esquema de pensamiento, una ideología cultural de la cual no podían escapar. Quizás a la manera de Foucault, se considera que los individuos del siglo XIX no podían escapar de su limitado horizonte cultural o episteme y que, por lo tanto, los europeos, no hicieron otra cosa que copiarse unos a otros repitiendo ad infinitum sus prejuicios racistas. De manera que su "mirada del otro" estaría siempre imbuida de su sentido de superioridad, a la vez que sus narraciones no expresaban otra cosa que la preparación ideológica para la dominación del subcontinente latinoamericano por el capitalismo industrial". 98

¿Invisibilizan esos relatos de viajes por completo las realidades y otredades del continente americano? ¿No hay otras líneas de percepción y pensamiento?

En el caso de alemanes por Centro-/Mesoamérica, sí, existen otras líneas y otras tradiciones, si pensamos solamente en viajeros-científicos como Julius Fröbel, Eduard Seler, Walter Lehmann, entre otros. Todos estos viajeros se ubican en una tradición que se diferencia de las líneas dominantes en los textos de los tres viajeros alemanes analizados y para la cual la obra de Alexander von Humboldt tiene suma relevancia. En contraposición a la tesis de Marie Louise Pratt, que define la obra de Humboldt como esencial y materia prima para ideologías americanas y americanistas acuñadas por intelectuales criollos en los años veinte, treinta y cuarenta del siglo XIX, ${ }^{99}$ hay que insistir en el carácter crítico,

descritas por ellos. Menciona explícitamente a Julios Fröbel, Wilhelm Heine y un ingeniero Reichardt: "Julius Fröbel ha descrito Nicaragua como un entusiasta y optimista de la naturaleza, pero también le agradecemos varias informaciones científicas valiosas. Tanto él como el pintor Wilhelm Heine pertenecen a los temperamentos fuertes, de mente abierta. Sus descripciones están llenas de vida; aunque Heine se permitió unos embellecimientos fantásticos [...] es insoportable el estilo de hacer libros de una colección de apuntes, la pedantería seca del reportero, en el cual se ve con mucha claridad que ya tenía conceptuado el resultado de su viaje antes de su partida de Europa. Pues, en verdad, para escribir un reporte como Reichardt, no se necesita haber estado uno mismo en Nicaragua [...]". Ibid, 187.

98 Solórzano, párrafo 73.

99 Ver Pratt, Ojos..., 321-322. Pratt construye una especie de pecado primario de Humboldt en relación con los proyectos criollos que se basaban en la exclusión de las culturas indígenas: "Su obra fue una piedra de toque para la literatura cívica que proclamaba la independencia literaria de Hispanoamérica, formulando interpretaciones de la realidad americana que eran orgullosamente americanistas y, al mismo tiempo, -como lo señaló el historiador cultural Pedro Henríquez Ureña-, no eran europeas sino europeizantes. Una y otra vez en los textos fundacionales de la literatura hispanoamericana, la estetizada América virgin de Humboldt brindó un punto de partida para la elaboración de prescripciones cívicas y morales para las nuevas repúblicas. Su reinvención de América para Europa fue transculturada por los euroamericanos a un proceso criollo de autoinvención. Esa transculturación y sus aspectos de selección e invención constituyen el foco de lo que sigue". Ibid. 
innovador e independiente del pensamiento humboldtiano. ${ }^{100}$ En este sentido, el único ensayo de Alexander von Humboldt, que nunca pisó tierra en Centroamérica, sobre el istmo publicado en 1826 es un ejemplo claro de esas dimensiones de su obra. ${ }^{101}$ Cabe resaltar, en particular, dos aspectos: la concepción de Humboldt sobre el proyecto de un canal interoceánico y su posicionamiento frente a lo que hoy llamaríamos la cuestión étnica. En contraposición a Heine y Marr, que discuten el proyecto del canal como parte de una "misión civilizatoria" de los Estados Unidos en Centroamérica; para Humboldt el proyecto dista de ser una empresa técnica de consolidación de la hegemonía geoestratégica y comercial de las grandes potencias mundiales: más bien es "un proyecto de integración y comunicación transatlántica y transareal de los pueblos y culturas de Centroamérica". ${ }^{102}$ En una carta al filósofo, político y periodista José Cecilio del Valle (1780-1834) de noviembre de 1825, en ese momento presidente de la República Federal de Centroamérica, "Humboldt le pide que como gobernante dirija constantemente sus esfuerzos a 'mejorar la clase de los indígenas y el estado de los negros' ya que 'la libertad no se consolida sino por el goce común de los bienes que la naturaleza concede a la sociedad humana" ". ${ }^{103}$

La misma Marie Louise Pratt no niega la posibilidad de cuestionar, romper con, subvertir el orden del discurso "euroimperialista". En su análisis de viajeras europeas hace visibles estas potencialidades, ${ }^{104} \mathrm{y}$ las ve incluso dominantes en escritores como Albert Camus y Richard Wright:

\section{“ 'La mujer adúltera' de Camus y Black Power de Wright fueron es- critos a mediados de la década de 1950 , cuando los conflictos colo- niales en muchas partes de África avanzaban rápidamente hacia la}

100 En este caso, coincido con el criterio de Solórzano: "El propósito de contrastar el pensamiento naturalista europeo y el de sus críticos en la Hispanoamérica colonial busca aclarar que es absolutamente errado hablar de un pensamiento monolítico durante la Ilustración -como han venido presentando los llamados 'estudios postcoloniales'-, y que, por el contrario, importantes intelectuales europeos durante el siglo XIX descubrirían a su vez a los autores hispanoamericanos que ya ofrecían una visión diferente sobre las culturas autóctonas americanas". Solórzano, párrafo 10.

101 Alexander von Humboldt, "Ueber den neuesten Zustand des Freistaats con Centro-Amerika oder Guatemala. Aus Korrepondenz-Nachrichten von Alexander von Humboldt", Hertha. Zeitschrift für Erd-, Völkerund Staatenkunde, 6, no. 2 (1826): 131-161. En 2011, se publicó una edición bilingüe de este ensayo en la Editorial de la Universidad de Costa Rica, con ensayos de Héctor Pérez Brignoli y Ottmar Ette y una introducción de Henning Jensen y Werner Mackenbach: Zentralamerika = Centroamérica / Alexander von Humboldt, (ed.) Héctor Pérez Brignoli, trad. Silvia Kruse (San José, Costa Rica: EUCR, 2011).

102 Henning Jensen y Werner Mackenbach, "Presentación”, en: Zentralamerika = Centroamérica ..., xiii.

103 Héctor Pérez Brignoli, "Centroamérica en la obra de Alexander von Humboldt", en: Zentralamerika = Centroamérica..., 27. Pérez Brignoli y Ottmar Ette, en su artículo en el mismo libro: "La ciencia humboldtiana y el ensayo sobre Centroamérica", Ibid, 1-17, sostienen que el ensayo de Humboldt sobre Centroamérica se basaba en los mismos fundamentos y dimensiones de su vasta obra, en general. Ver acerca de esta obra los numerosos estudios de Ottmar Ette, entre ellos especialmente: Alexander von Humboldt und die Globalisierung. Das Mobile des Wissens (Frankfurt am Main, Leipzig: Insel Verlag, 2009); Weltbewußtsein. Alexander von Humboldt und das unvollendete Projekt einer anderen Moderne (Weilerswist, Alemania: Velbrück Wissenschaft, 2002).

104 Ver Pratt, Ojos..., 379-387. 
Entre Imperial Eyes e "Información fidedigna". Reflexiones sobre la representación de América Central en textos de viajeros alemanes

confrontación violenta. Ambos textos están directamente ligados a momentos específicos en las luchas por la descolonización. Los cuentos de Camus datan del comienzo de la brutal guerra franco-argelina que Fanon estudió como un paradigma de los horrores de la moderna violencia colonial. [...] Wright asistió a la fundación de la nación independiente de Ghana, ex Costa de Oro inglesa, un evento que llegó a convertirse en un paradigma para el desmantelamiento pacífico de los aparatos coloniales. El francoargelino y el afroamericano [...]. El poder negro y el adulterio cultural que imaginaron en sus noches africanas de la década de 1950 dan testimonio de ciertas aperturas en las estructuras de la dominación occidental y la ideología colonialista dentro de la metrópoli, aperturas hacia las que la literatura y el pensamiento de los movimientos de liberación del Tercer Mundo fluyeron en las décadas de 1960 y 1970. En esas dramáticas décadas, el lamento del hombre blanco se desplegó en contacto con voces contestatarias que cada vez más tomaban la palabra". ${ }^{105}$

Cabe destacar que Marie Louise Pratt, por un lado, ve este potencial para salir del discurso imperial/imperialista dominante estrechamente vinculado con el estatus de gender de las mujeres viajeras, "explorer-women" y "explorer-wives", en sus viajes por África, para las que "[e]l discurso heroico y masculino del descubrimiento no es fácilmente accesible", ${ }^{106}$ pero al mismo tiempo sostiene que les caracteriza "una voz femenina monárquica que afirma su tipo de dominación, aun cuando niegue la dominación y se burle del poder"107. Por el otro lado, son los viajeros que llama "hyphenated" hombres, es decir hombres con guión -como el franco-argelino Camus y el anglo-africano Wright-, quienes, por su vivencia/convivencia en dos culturas, comienzan a cuestionar el imperio desde dentro. ${ }^{108}$ Sin lugar a dudas, es una consecuencia de su colocación y sus movimientos en lo que Pratt llama "zonas de contacto", sin que estas potenciales dimensiones subversivas de la escritura de viajeros "con guión" la llevaran a repensar este término en su carácter plural e incluso contradictorio; más bien, lo reduce a sinónimo de "frontera colonial":

"[...] espacios sociales donde culturas dispares se encuentran, chocan y se enfrentan, a menudo dentro de relaciones altamente asimétricas de

105 Ibid, 400-401. Pratt se refiere a: Richard Wright, Black Power (New York, EE. UU.: Harper, 1954) y Albert Camus, "The Adulterous Woman", en: Exile and the Kingdom, trad. Justin O'Brien (New York, EE. UU.: Vintage Books, 1957), 4-13.

106 Pratt, Ojos..., 379.

$107 \mathrm{Ibid}, 380$. En su análisis hace referencia particular a la científica británica Mary Kingsley que viajó por África en los años noventa del siglo XIX y a su libro: Travels in West Africa (London, Inglaterra: Macmillan \& Co., 1897).

108 En la traducción de "A hyphenated Frenchman and a hyphenated American [...]" -Pratt, Imperial..., 224al español se pierde esta idea del "hombre con guión": "El francoargelino y el afroamericano [...]" -Pratt, Ojos..., 400-401-. 
dominación y subordinación, tales como el colonialismo, la esclavitud, o sus consecuencias como se viven en el mundo de hoy". ${ }^{109}$

$¿$ “Es entonces posible e idóneo el uso de estos documentos como fuente de información de primera mano", para no incurrir "en una pérdida enorme de lo que se puede aprender de los viajeros", como sostiene enfáticamente Juan Carlos Solórzano en abierta crítica de los estudios poscoloniales? ${ }^{110}$

Con base en el análisis de los textos de tres viajeros alemanes propuesto en el presente ensayo, me parece pertinente partir de algunas premisas formuladas por Stephen Greenblatt en relación con los textos de los primeros viajeros y conquistadores europeos por América:
"[...] I want $[\ldots]$ to sum up the principles that seem to me to characte- rize the new directions in New World scholarship, principles that bring together the very different enterprises of history, ethnography, and li- terary criticism. First, an assumption of textual opacity. We must start from the conviction that discourse neither can nor should be rendered transparent. [...] Second, a search for textual otherness. The voices of the other do not reach us in pure or uncontaminated form -as if such condition were ever possible! [...] A third principle [...] is clo- sely linked with the skeptical reading practice I have just sketched: a recognition of textual complexity. The early European accounts of the encounter are not monolithic or single-minded. [...] Fourth, [...] a related questioning of textual authority. Once they are written, texts do not simply appear in the world (or routinely survive in archives): they are marked, placed, licensed, authorized". ${ }^{111}$

109 Ibid, 31 y 33. Más ampliamente lo define así: "Uno de éstos [términos y conceptos] que reaparece a lo largo de todo el libro es el de zona de contacto, que uso para referirme al espacio de los encuentros coloniales, el espacio en el que personas separadas geográfica e históricamente entran en contacto entre sí y entablan relaciones duraderas, que por lo general implican condiciones de coerción, radical inequidad e intolerable conflicto. Aquí el término contacto ha sido tomado de la lingüística, en la que la frase lengua de contacto se refiere a lenguajes improvisados que se desarrollan entre hablantes de distintas lenguas que necesitan comunicarse continuamente, por lo general dentro del contexto de las relaciones comerciales. Esas lenguas empiezan como una suerte de pidgin y luego, en el momento en que producen hablantes nativos, se les llama lenguas creole o "criollas". Al igual que las sociedades de la zona de contacto, esos idiomas son considerados, por lo general, caóticos, bárbaros, carentes de estructura”. Ibid, 33.

110 Solórzano, párrafos 82 y 75.

111 " [...] quisiera resumir [...] los principios que a mi criterio caracterizan las nuevas tendencias en los estudios académicos sobre el Nuevo Mundo, principios que reúnen los diversos proyectos de la historia, la etnografía y la crítica literaria. Primero, una asunción de opacidad textual. Debemos partir de la convicción de que el discurso no puede ni debe ser visto como transparente. [...] Segundo, una búsqueda de la otredad textual. Las voces de los otros no nos alcanzan en una forma pura o libre de contaminación -icomo si esta condición fuera siquiera posible! [...] Un tercer principio [...] está estrechamente vinculado con la práctica escéptica de la lectura que acabo de esbozar: un reconocimiento de la complejidad textual. Los primeros relatos europeos no son monolíticos ni unívocos. [...] Cuarto, [...] un cuestionamiento análogo de la autoridad textual. Una vez escritos, los textos no aparecen simplemente sobre la Tierra -o sobreviven rutinariamente en archivos-: son marcados, ubicados, legitimados, autorizados". Stephen Greenblatt, "Columbus Runs Aground: Christmas Eve, 1492”, en: Counting \& Recounting. Measuring Inner and Outer 
Entre Imperial Eyes e "Información fidedigna". Reflexiones sobre la representación de América Central en textos de viajeros alemanes

Para intentar iluminar esa opacidad de los textos, para hacer audibles las voces del Otro ser, para comprender la complejidad textual de los documentos y para examinar críticamente su autoridad textual -por lo menos parcialmente- y así superar fundamentalismos, reduccionismos e ingenuidades, es imprescindible recurrir a procedimientos metodológicos y enfoques conceptuales y teóricos de diferentes campos del saber; es decir, requiere un trabajo inter si no transdisciplinario -especialmente, entre especialistas de las disciplinas de historia, lingüística, antropología, estudios literarios y culturales, entre otras-. ${ }^{112}$ Este trabajo puede recibir aportes importantes de la ya mencionada imagología ${ }^{113}$, de la narratología ${ }^{114}$, de los estudios sobre la construcción hemisférica del "Nuevo Mundo" en Europa y las Américas ${ }^{115}$ y de los estudios de la literatura de viajes. ${ }^{116}$

Partiendo de la diferenciación entre dicción y ficción y entre relato factual y relato ficcional propuesta por Gérard Genette, ${ }^{117}$ Ottmar Ette define la literatura de viaje como "literatura friccional" caracterizada "por una singular oscilación entre ficción y dicción, por un vaivén continuo que impide una clasificación estable tanto en lo referente a la producción como a la recepción". ${ }^{118}$ Con base en

Space in the Renaissance, (eds.) Paola Bottalla y Michela Calderaro (Trieste, Italia: Edizioni La Mongolfiera, 1995), 22-25 -trad. Mauricio Chaves-.

112 En otro lugar propuse una triple (re)lectura científico-crítica de estos textos: "1) Una lectura histórica, mejor dicho, historiográfica [...] 2) Una lectura comparada dentro de la literatura alemana [...] 3) Una lectura comparada en el marco de la literatura centroamericana [...]". Ver Mackenbach, "De notas...", $160-161$.

113 Ver nota al pie 53. Cabe señalar el carácter transhistórico de los imagotipos analizados por Siebenmann en la cultura de los países de habla alemana.

114 Ver los estudios de Gérard Genette sobre las diversas dimensiones de la hiper-, inter- y paratextualidad, especialmente: Palimpsestos. La literatura en segundo grado, trad. Celia Fernández Prieto (Madrid, España: Editorial Taurus, 1989), y Umbrales, trad. Susana Lage (México, D.F.: Siglo XXI Editores, 2001). También los conceptos de hipertextualidad y especialmente de architextualidad, "el conjunto de categorías generales o transcendentes -tipos de discurso, modos de enunciación, géneros literarios, etc.- del que depende cada texto singular" -Genette, Palimpsestos..., 9- tienen una dimensión transhistórica, en el sentido propuesto en la nota al pie 5 .

115 Ver, entre otros, los estudios de Tzvetan Todorov y Frauke Gewecke: Tzvetan Todorov, La Conquista de América. La cuestión del otro, trad. Flora Botton Burlá (México, D.F.: Siglo XXI Editores, 1987), y Frauke Gewecke, Wie die neue Welt in die alte kam (Múnich, Alemania: Deutscher Taschenbuch Verlag/Klett-Cotta, 1992).

116 Ver particularmente: Ottmar Ette, Literatura en movimiento. Espacio y dinámica de una escritura transgresora de fronteras en Europa y América, trad. Rosa María S. de Maihold (Madrid, España: Consejo Superior de Investigaciones Científicas, 2008).

117 Ver Gérard Genette, Ficción y dicción, trad. Carlos Manzano (Barcelona, España: Editorial Lumen, 1993).

118 Ette, Literatura ..., 42. "El relato de viajes es, como la novela, una forma híbrida", sostiene Ette y continúa: "Sin embargo, a diferencia de ella, no está sujeto al polo ficcional -tanto desde la estética de recepción como de la producción- en el campo de tensión que se produce entre las formas textuales ficcionales y las no ficcionales. Si por lo general se puede colocar la novela en el polo de la ficción, vale preguntar por el lugar en el cual se podría acomodar, por contraste, el relato de viajes. Podemos concluir de lo anterior que es completamente legítima una lectura que sitúe el relato de viajes en el polo de lo no ficcional y que se lean las informaciones por él transmitidas como documentos y fuentes; sin embargo, una lectura de ese tipo no puede -y no podría nunca- agotar el género en sí. Más bien se ha puesto de relieve que el relato de viajes -y no 'sólo' en su variante fantástica- atrae hacia sí modelos de lectura ficcionales y no ficcionales uniéndolos a menudo de manera indisoluble. ¿Entonces, dónde colocar el relato de viajes? [...] Entre los 
esta propuesta, Ette desarrolla un análisis de las dimensiones espaciales de la literatura de viaje, tanto en lo referente a los lugares representados en el texto y los lugares textuales como a los movimientos topográficos representados por el texto y los movimientos hermenéuticos del texto en el texto, ${ }^{119}$ que también aportan aspectos muy sugerentes al análisis de los textos de los tres viajeros alemanes realizado en el presente ensayo.

"Sólo el retorno a Europa [...] hará posible dar forma a buena parte del Nuevo Mundo en el Viejo Mundo", escribe Ette en relación con el Diario de a bordo de Cristóbal Colón y los tempranos relatos de los conquistadores y continúa: "Es precisamente el retorno el que le confiere sentido al movimiento de viaje de Colón". ${ }^{120}$ Es decir, la empresa del almirante al servicio de la Corona Española no se desarrolla "sólo bajo el signo de la cruz, sino también bajo el signo del círculo". ${ }^{121}$ Como los viajes de los primeros conquistadores y cronistas se realizan en permanente referencia y reflexión al viejo continente, así también los textos de los viajeros del siglo XIX y XX analizados se caracterizan por esta visión. No solamente los movimientos topográficos de los tres alemanes se realizan en forma de círculo: salida/despegue de Alemania/ llegada a Alemania. También el espacio textual tiene una estructura circular -la despedida y la llegada ocupan lugares estratégicos en el espacio textual-, ${ }^{122}$ y la semantización de las representaciones espaciales se hace-necesariamente-a través de comparaciones con el viejo mundo y con figuras retóricas, especialmente metáforas, prestadas de las culturas y literaturas europeas. Finalmente, también en los movimientos hermenéuticos, que emprenden durante sus viajes topográficos y que fijan en el espacio textual, los tres también se quedan atrapados en un círculo vicioso. ${ }^{123}$ Se percibe, comprende y (re)presenta el "Nuevo Mundo" en función de su po-

polos de la ficción y la dicción, el relato de viajes nos lleva [...] a una fricción, puesto que se evitan el establecimiento de limitaciones bien definidas, así como los intentos de realizar amalgamas estables y formas mixtas. A diferencia de lo que ocurre con la novela, el relato de viajes constituye una forma híbrida no sólo a consecuencia de los géneros que incluye y su variedad de discursos, sino también por su capacidad de sustraerse a la oposición entre ficción y dicción. El relato de viajes ha limado las fronteras entre los dos ámbitos [...]". Ibid, 41-42.

119 Ver Ibid, 23-67.

$120 \mathrm{Ibid}, 72$.

121 Ibid.

122 Ver la recarga semántica de la salida y la llegada y correspondientemente del íncipit y del final del libro en los textos de Heine y Marr, así como las anotaciones de Kroetz al inicio y al final de su Nicaragua-Tagebuch, que fueron escritas en Alemania o se refieren a Alemania. Ver acerca de los diferentes lugares de la literatura de viajes Ette, Literatura..., 38-51.

123 Acerca de la percepción y la representación del espacio latinoamericano en las literaturas europeas y latinoamericanas, ver el siguiente estudio: Andrea Mahlendorff, Literarische Geographie Lateinamerikas. Zur Entwicklung des Raumbewußtseins in der lateinamerikanischen Literatur (Berlin, Alemania: Edition Tranvía, 2000); sobre la relación entre la dinámica espacial topográfica y hermenéutica en la literatura de viajes y otros textos -literarios- ver: Ette, Literatura ...; para una discusión crítica de la relevancia de ambos estudios para el análisis de la relación entre espacio y texto ver: Werner Mackenbach, Die unbewohnte Utopie. Der nicaraguanische Roman der achtziger und neunziger Jahre (Frankfurt am Main: Vervuert, 2004), 348-365. 
sicionamiento en el viejo mundo, sea -como en Heine y Marr- para transmitir conocimientos sobre la "América española", ${ }^{124}$ sea -como en Kroetz- con la intención de alejarse de la situación apremiante en Alemania y de ganar una nueva motivación para la escritura literaria en Alemania a través de las experiencias en Nicaragua. ${ }^{125}$ También, en este respecto, Kroetz se diferencia de los otros dos por su lenguaje directo y sin paliativos: "De vez en cuando pierdo el coraje, entonces tengo un miedo muy primitivo de no poder regresar A CASA, sino quedar pegado aquí", anota a mediados de su diario y continúa: "Eso va y viene y una hora más tarde pienso seriamente: mejor ser sepultado aquí que en la jodida Alemania". ${ }^{126}$ Pero al final de su viaje/libro su mirada se fija otra vez en Alemania. Acerca de un conflicto con su amante R., quien quiere quedarse en Nicaragua y trabajar allá, escribe:

"[...] si no le hubiera prometido a Dietl aceptar el rol de Baby Schimmerlos en KIR ROYAL y al teatro íntimo de Múnich la nueva pieza y si hubiera... sí, entonces me quedaría; lo apunto en toda su insignificancia y muy desenmascaradamente. Sé honesto". ${ }^{127}$

Y admite: "R. tuvo razón. Qué despedida más deplorable."128

A pesar, y más bien, por las estructuras hermenéuticas en las que se basan, esos textos de viajes son documentos de un valor significativo para el estudio de las relaciones entre Europa y América (Latina) y sus representaciones en las literaturas alemana/europeas, así como las latino-/centroamericanas, pus son ejemplos -para decirlo así- del lado "sucio" de la tradición alemana/europea de la percepción viajante o de los viajeros percibientes. Para una comprensión intercultural de las relaciones Europa/Alemania-América (Central), el análisis de estos textos tiene tanta relevancia como el de los "grandes" conocidos Alexander von Humboldt, Julius Fröbel, Walter Lehmann, etc., porque muchas veces articulan más inmediatamente las tendencias generales y dominantes de su tiempo.

124 Marr, Reise..., tomo I, XI -traducción mía-, ver, en general, VII-XII. Ver también Heine, Impresiones..., 39-48. Heine dedica su libro - en un movimiento "hermenéutico-pasional" circular- a su "querida Marie" en Alemania:

"Mi querida Marie! [...] las relaciones de viaje aquí contenidas no son más que señales de vida y amor para Ustedes en la madre patria, te dedico estas mismas a ti”. Ibid, 5 .

125 Ver Kroetz, 13, 16, 17.

126 Ibid, 99.

127 Ibid, 158-159. Kir Royal fue una serie de la televisión alemana en seis partes, con la dirección de Helmut Dietl sobre el periodismo sensacionalista emitida en 1986, en la que Franz Xaver Kroetz tuvo el rol del periodista Baby Schimmerlos.

$128 \mathrm{Ibid}, 159$. 